\title{
The EMU and the NAMU:
}

\section{What is the Case for North American}

\section{Monetary Union?}

\author{
WiLlem H. BUITER \\ Professor of International Macroeconomics, University of Cambridge and \\ Member, Monetary Policy Committee, Bank of England
}

Cet article examine les avantages et inconvénients qui s'expriment dans le débat sur l'union monétaire entre le Canada et les États-Unis. On compare le système actuel avec un taux de change flexible et un niveau cible d'inflation, avec l'adoption unilatérale du dollar américain ainsi qu'avec une union monétaire symmétrique et complète. Au niveau microéconomique, la réduction des coûts de transactions favorise ces deux types d'union. Les considérations seigneuriale vont à l'encontre d'une union unilatérale mais favorisent une union monétaire symmétrique. De plus, la perte du rôle de prêteur de dernier recours est un argument important contre une union monétaire unilatérale. Les arguments sur la zone optimale de la monnaie (qui concerne, au niveau macroéconomique, les aspects de stabilisation du taux de change pré-déterminé) favorisent probablement les deux types d'unions. D'un autre côté, les capacités d'un taux de change flexible d'absorber les chocs sont liées aux instabilités et à la volatilité excessive qui existent avec un taux de change déterminé par les conditions de marché lorsque les marchés financiers atteignent un degré d'intégration élevé. En résumé, les arguments économiques favorisent une union monétaire complète et symmétrique et non l'adoption unilatérale du dollar américain.

Puisqu'il n'y a pas d'institutions politiques démocratiques communes aux États-Unis et au Canada, les arguments politiques contre l'une ou l'autre de ces unions sont très importants. Sans un Accord sur l'Union Politique Nord-Américain, le transfert de la souveraineté nationale à une banque centrale supranationale n'aurait pas de légitimité politique. Étant donné le manque d'institutions pouvant garantir la responsabilité politique d'une Banque Centrale Nord-Américaine, une Union Monétaire Nord-Américaine, si elle se produit, a peu de chances de survivre.

The paper considers the pros and cons for Canada of monetary union between Canada and the United States. The current Canadian monetary arrangements, a flexible exchange rate and an inflation target, are contrasted both with a unilateral adoption by Canada of the US dollar and with a full, formally symmetric monetary union. Microeconomic transactions costs savings argue in favour of either form of monetary union. Seigniorage considerations argue against unilateral adoption of the US dollar, but in favour of a formally symmetric monetary union. Loss of the lender of last resort is a powerful argument against unilateral monetary union. The optimal currency area arguments (which concern the macroeconomic stabilization aspects of a permanently fixed exchange rate) probably favour either form of monetary union. The shock-absorber properties of a flexible exchange rate are dominated by the extraneous instability and excess volatility inherent in a market-determined exchange rate when financial markets are highly integrated. On balance, the economic arguments favour a full, formally symmetric monetary union but not the unilateral adoption of the US dollar.

Because of the absence of any democratic political institutions spanning both Canada and the United States, the political arguments against any form of monetary union are overwhelming. Without a North American political union, the transfer of national sovereignty to a supranational central bank would lack political legitimacy. The lack of institutions for ensuring the political accountability of a North American Central Bank means that NAMU is unlikely to happen and that, if it were to happen, it is unlikely to survive. 


\section{INTRODUCTION}

$\mathrm{C}$ urrency regimes are under review everywhere. Not only in transition economies, developing countries and emerging market economies, but also in some of the most industrially advanced countries of the world. On 1 January 1999, 11 of the 15 European Union (EU) members successfully launched their common currency, the Euro, by pooling their national monetary sovereignties in a common, supranational monetary sovereignty, institutionally expressed in a "unitary" supranational central bank, the European Central Bank (ECB), with the member national central banks (NCBs) reduced to a role rather like that of regional reserve banks in the Federal Reserve System. ${ }^{1}$

In view of these epochal changes taking place in Western Europe, it is not surprising that the question has been raised as to whether the European monetary union (EMU) might be an appropriate model for North America (the United States, Canada and Mexico). ${ }^{2}$ In what follows I will review the main issues that determine the answer to that question. My discussion will mainly focus on the pros and cons of monetary union between the United States and Canada, although many of the relevant considerations are applicable to Mexican membership in a North American monetary union (NAMU) as well.

I will restrict the discussion to a comparison of just two currency regimes. The first is a continuation of the current Canadian arrangement: a floating exchange rate and a slightly opaque inflation target. ${ }^{3}$ The second is a monetary union with the US. Here I distinguish between two kinds of monetary union. The first kind is a full and formal monetary union, what I will call a (formally) symmetric monetary union. ${ }^{4}$ Canada would get its fair share of the NAMU-wide seigniorage; financial institutions in all member nations would have access to the discount window of the NAMUFed on equal terms; the NAMUFed would act as lender of last resort on the same terms and conditions in all member nations; and the monetary policy of the NAMUFed would be directed at price stability and economic activity in the NAMU area as a whole. Effectively, from a monetary point of view, Canada would be the thirteenth Reserve District of the Federal Reserve System, and would have a permanent seat on the Fed Open Market Committee (FOMC).

The second kind of monetary union would be the unilateral adoption by a country (Canada) of the currency of another nation (the US dollar) as the only legal tender. ${ }^{5}$ I will refer to this kind of monetary union as an asymmetric monetary union. Such unilateral "(US-) dollarization" would not provide Canada with a share of the seigniorage revenues of the common currency area. There would be no access to the Fed discount window. The Fed would not have any lender of last resort responsibilities visà-vis the financial institutions of Canada. There would be no seat on the FOMC and monetary policy by the Fed would be conducted purely in the US national interest, as perceived by the FOMC.

There are many other possible arrangements. An adjustable currency peg vis-à-vis the US dollar (or vis-à-vis a basket of currencies) is one. Another is a currency board, a legislatively fixed exchange rate (presumably vis-à-vis the US dollar) with 100 percent reserve backing of domestic currency issue. A third is a legislatively fixed exchange rate without 100 percent reserve backing of domestic currency issue, that is, with scope for domestic credit expansion.

Even if we restrict ourselves to floating or flexible exchange rate regimes, there is a wide range of

Douglas Purvis Memorial Lecture, given at the Canadian Economic Association 1999 Conference, Toronto, on Saturday 29 May 1999. 
possible objectives and at least two choices of monetary instruments to consider. Single nominal targets, such as inflation targets or price level targets are one, currently popular, option. Multiple targets, for instance an inflation target augmented with output gap or unemployment objectives are other popular candidates. ${ }^{6}$ The ordering of the targets can either be lexicographic, as in the United Kingdom and in the EMU zone, or more symmetric, with nonzero weights attached to all objectives, as in the US. The horizon over which the target or targets are to be pursued can differ, as can the operational definition of the inflation target.

There is no modern central bank that does not have price stability as at least one of its targets. An interpretation of the current Canadian monetary arrangements as one of pursuing the objective of price stability through a low target for the inflation rate of a broadly based consumer price index, containing both domestically produced and imported goods and services, seems reasonable (see e.g., Thiessen 1998, 1999; and Freedman 1995). ${ }^{7}$ Even if the Canadian inflation target is not formally symmetric, the existence of a range with a lower bound of 1 percent does put a floor under how far real economic activity can weaken in response to a contractionary shock to aggregate demand, just as the upper bound of 3 percent sets a ceiling on how high inflation can go. It is not completely clear to me whether the stabilization of output and employment around their capacity or natural levels is a subsidiary objective in its own right, or an implication of the pursuit of a symmetric inflation target, when the majority of the shocks hitting the economy are shocks to aggregate demand.

In a floating exchange rate world, there are two options as regards the choice of the monetary instrument: ${ }^{8}$ the monetary base and a short nominal interest rate. Changes in the monetary base can have as their counterpart, on the asset side of the central bank balance sheet, either changes in external reserves or changes in domestic credit. In a world with unrestricted international capital mobility, the composition of the asset side of the central bank's bal- ance sheet is irrelevant. Sterilized foreign exchange market intervention then has no effect on anything, nominal or real. In practice, no central bank I know of has ever practised monetary base control. The reason is that the velocity of circulation of the monetary base is far too noisy to make the monetary base a desirable instrument of monetary control. This leaves the cost of borrowing the monetary base, that is, the short risk-free nominal rate, as the universal monetary instrument of choice.

In a world with unrestricted financial capital mobility and an imperfect capacity for commitment to the defence of the external value of the currency, an adjustable peg is an accident waiting to happen (see Buiter, Corsetti and Presenti 1998). A legislatively fixed exchange rate (with or without the additional currency board feature) is either not fully credible, in which case it is simply another version of an adjustable peg, or it is fully credible, in which case it is an inferior substitute for full monetary union in every respect except as regards some of the symbolic trappings of national sovereignty (below).

I approach the question about the pros and cons of NAMU by asking why the currency regime matters. In the next section I review the technical economic arguments for and against NAMU, starting with the microeconomic benefits of a common medium of exchange and the microeconomic costs of the change-over. Next is the question of seigniorage - the real resources appropriated by a national government through the issuance of non-interestbearing liabilities. The third issue is systemic financial stability and the role of the national central bank as the lender of last resort. The last economic issue is the costs and benefits of national monetary sovereignty and exchange rate flexibility from the point of view of macroeconomic stabilization policy. This is the venerable subject of optimal currency areas. Section three considers the political and constitutional arguments for and against NAMU: the substance and symbols of national sovereignty and the issue of accountability of the monetary policymakers to the electorate. The conclusion follows. 


\section{Why Does the Currency Regime Matter? ECONOMIC ARGUMENTS}

\section{The Microeconomics of a Common Currency}

The transactions cost-saving advantages of a common currency are familiar. A medium of exchange or transactions medium is subject to a network externality (Dowd and Greenaway 1993). The usefulness to me of a medium of exchange is increasing in the number of other economic agents likely to accept it as a medium of exchange. By eliminating the need for the exchange of one currency for another, real resource costs are saved. From a microeconomic efficiency point of view, if one were to design the world from scratch, a single currency would be adopted.

If the status quo is a situation in which there are multiple national currencies, the permanent flow of transaction cost savings from having a common currency have to be balanced against the one-off, upfront switch-over costs of moving to a common currency. For Canada, these switch-over costs are likely to be lower than for the countries that joined the EMU, since most Canadians are familiar with the US dollar already. Little can be said about the magnitude of the resource savings involved. The spreads in the foreign exchange markets will understate the true cost because it ignores the "in-house" costs incurred by the non-bank parties in the foreign exchange transactions. It overestimates the true costs to the extent that there are monopoly profits or Xinefficiency in the foreign exchange markets.

In its report One market, one money (European Economy 1990), the Commission of the European Communities estimated the permanent flow of exchange transaction costs savings at about 0.5 percent of gross domestic product (GDP) for the 15 member Community as a whole. Of course, this exercise involved the abolition of 14 national currencies and their replacement by a single currency. NAMU would involve replacement of one or two currencies by a common currency if a full, formally symmetric monetary union is involved, or the abolition one or two currencies if unilateral (US) dollarization is considered. The foreign exchange transaction costs savings should also be augmented by the transactions costs saved in transactions between instruments denominated in national currencies that would be redundant if a common currency were adopted. For example, an investor could decide to switch from Canadian Treasury bills (TBs) to US Treasury bills because of currency risk considerations. ${ }^{9}$ This would involve the sale of the Canadian TBs, a purchase of US dollars and the purchase of the US TBs. There would be three transactions, and three sets of transaction costs. Foreign exchange market transaction costs are just one of the three. One-half of 1 percent of GDP (if that is indeed a reasonable estimate) may not sound like much, but it is twice the maximal estimate of the amount of seigniorage Canada currently gets from note issuance (see Table 1).

The magnitude of the switching costs for Canada are even harder to estimate. In the case of EMU, competing estimates differed by one and sometimes two orders of magnitude. The switching costs do not just involve the administrative and hardware cost of re-denominating all contracts, changing vending machines, etc. but also the psychological costs of having to compute prices with a new numeraire. With boundedly rational individuals, these costs will always be there, but they are likely to be less significant in the case of Canada adopting the US dollar, because most Canadians are already very familiar with this currency. Adopting an altogether new currency would involve higher re-computation costs of this kind.

A final microeconomic benefit from a common currency is the greater price transparency it creates. Price discrimination and market segmentation are discouraged when buyers can more easily engage in comparison shopping. Again, this argument relies on bounded rationality, and the magnitude of these benefits is anyone's guess. 
TABLE 1

Seigniorage in Canada

\begin{tabular}{ccccc}
\hline & $\begin{array}{c}\text { Seigniorage } \\
\text { (C\$ billion) }\end{array}$ & $\begin{array}{c}\sigma \\
\text { Seigniorage } \\
(\% \text { of GDP) }\end{array}$ & $\begin{array}{c}\omega^{* *} \\
\text { Interest Bill Foregone } \\
(\% \text { of GDP) }\end{array}$ & $\begin{array}{c}\tau^{* * *} \\
\text { Inflation Tax } \\
(\% \text { of GDP) }\end{array}$ \\
\hline 1994 & 1.76 & 0.23 & 0.21 & 0.01 \\
1995 & 0.90 & 0.11 & 0.22 & 0.07 \\
1996 & 0.86 & 0.10 & 0.14 & 0.05 \\
1997 & 1.39 & 0.16 & 0.13 & 0.05 \\
1998 & 2.52 & 0.28 & 0.17 & 0.03 \\
\hline
\end{tabular}

Notes: * Change in stock of currency over the previous year, measured at end of $Q B$

** Interest rate is one year TB rate

*** Inflation rate is CPI inflation rate

\section{Seigniorage}

There are several ways of measuring the resources appropriated by the state through the issuance of non-interest-bearing liabilities. In Canada, both components of the monetary base (currency and banks' balances with the central bank) are unremunerated, so one straightforward measure of state revenue from the activities of the central bank is simply the change in the monetary base. To get a sense of magnitude, it is helpful to express this as a fraction of nominal GDP. Letting $M_{t}$ denote the nominal stock of base money at the end of period t, $P$ the price level and $Y$ real GDP, I defined seigniorage, $\sigma$, as follows:

$$
\sigma \equiv \frac{M_{t}-M_{t-1}}{P_{t} Y_{t}}
$$

An alternative measure considers the interest bill foregone by having non-interest-bearing rather than interest-bearing liabilities. I denote this $\omega$. Let $i$ be the short risk-free nominal interest rate, then

$$
\omega_{t} \equiv i_{t} \frac{M_{t-1}}{P_{t} Y_{t}}
$$

A related measure of the monetary revenue of the state is the inflation tax, the reduction in the purchasing value of the outstanding stock of base money. I will refer to this as the anticipated inflation tax, denoted $\tau$. Let $\pi$ be the rate of inflation, ${ }^{10}$ then

$$
\tau_{t} \equiv \pi_{t} \frac{M_{t-1}}{P_{t} Y_{t}}
$$

The three measures are related. Let $m$ be the base money-GDP ratio ${ }^{11}$ and $g$ the growth rate of real GDP, ${ }^{12}$ then

$$
\sigma_{t} \equiv \tau_{t}+\frac{g_{t}}{1+g_{t}} m_{t-1}+\Delta m_{t}
$$

and

$$
\sum_{j=0}^{\infty} \prod_{k=0}^{j} \frac{1}{1+r_{t+k}} \sigma_{t+j} \equiv \sum_{j=0}^{\infty} \prod_{k=0}^{j} \frac{1}{1+r_{t+k}} \omega_{t+j}-\frac{1}{1+r_{t}} m_{t-1}
$$

Whatever the measure one uses, the revenues from the national printing presses are small beer for 
both Canada and the United States, although they have been more important for Mexico. Table 1 provides some illustrative seigniorage figures for Canada. I approximate the monetary base by the stock of currency outstanding. Seigniorage (the change in the stock of currency) has not been more than 0.28 percent of GDP since 1994. The interest bill foregone and inflation tax figures are even lower. This reflects the very low ratio of currency to GDP in Canada, barely more than 3 percent of annual GDP in recent years. The dollar numbers for seigniorage and the interest bill foregone, are roughly in line with the total revenue from investments reported by the Bank of Canada. The 1998 figure was $\$ 1.8$ billion, the lion's share of which ( $\$ 1.7$ billion) was paid to the Government of Canada (Bank of Canada 1999).

If Canada were to be able to negotiate a population-based or GDP-based share of NAMU-wide seigniorage, it could gain more seigniorage revenue than under national monetary autonomy. ${ }^{13}$ The reason is that US dollar seigniorage is vast and growing. US dollar notes are used the world over as means of payment and store of value by operators in the grey, black and outright criminal sectors of the economy, as well as by legitimate operators in countries with underdeveloped and/or highly unreliable domestic monetary and financial systems.

[Federal Reserve] board staff estimate that, as far back as 1960, a bit less than half of all US currency in circulation was held abroad. That proportion has grown steadily over the last four decades and has accelerated during the 1990s. As much as two-thirds of all Federal Reserve notes in circulation - perhaps $\$ 250$ to $\$ 300$ billion are now held abroad (Allison 1998, p. 1).

Negotiating a share of this larger and faster growing pie might be beneficial to Canada. The US is likely to be less keen on the idea.

Neoclassical optimal public finance arguments suggest that, if the fiscal authorities do not have non- distortionary taxes at their disposal, the distortionary inflation tax will be used, together with all other distortionary taxes, in such a way as to minimize the inevitable distortions and efficiency losses, now and in the future, associated with the financing of any given public spending program. If nations differ in the effectiveness of their tax administration, different national inflation rates may be optimal. Even in the rarified world of these neoclassical public finance models, this argument is by no means robust. Money is an asset, as well as a medium of exchange, and there is a considerable literature suggesting that, at least in steady state, assets should not be taxed. Money can also be thought of as an intermediate input in the process transforming primary inputs into goods and services available for household consumption. There is another body of literature suggesting that taxing intermediate inputs is undesirable.

Whatever the merits of this literature, the data make it clear that modern industrial states with welldeveloped financial systems do not make use of the inflation tax to any significant extent.

I conclude that loss of national discretion over seigniorage is not an economic obstacle to monetary union in North America, especially if a reasonable sharing rule is in place to distributed NAMU-wide seigniorage among the participants. Countries that decide to "dollarize" unilaterally, say by declaring the US dollar to be (the only) legal tender in their jurisdiction, cannot count on any share of dollar seigniorage and would be worse off.

The loss of national control over the national inflation rate could be more costly from the point of view of the broadly defined inflation tax, which consists not only of the reduction in the purchasing power of the national base money stock (the anticipated inflation tax) but includes the reduction in the market value of all nominally denominated government debt, including its interest-bearing liabilities (the unanticipated inflation tax). One can visualize dire circumstances when the ability to impose a 
capital levy on the holders of nominal public debt (especially longer-maturity debt) through an unexpected increase in the inflation rate might be a valuable policy instrument.

\section{Financial Stability: The Lender of Last Resort}

The state has a unique responsibility for dealing with systemic financial instability. The reason is that the state has deeper pockets than any private domestic agent. The state has the monopoly of the legitimate use of coercion and force. This is expressed through its power to tax, to declare certain of its liabilities to be legal tender, and to regulate. The central bank is the state agency with the short-term deep pockets, derived from its ability to issue legal tender. If a financial crisis is not a short-lived phenomenon (a liquidity or rollover crisis), but becomes a long-term solvency crisis for a substantial part of the financial sector, the short-term deep pockets of the central bank must be supplemented with the long-term deep pockets of the Ministry of Finance. A central bank that attempts to recapitalize a sizeable chunk of a bankrupt private financial sector's balance sheet would undermine its own solvency. Since the central bank does not itself have the power to tax, central bank solvency could be safeguarded only by continued monetary issuance, which would be inflationary. Non-inflationary recapitalization of a bankrupt financial system requires the resources of the state agency with the long-term deep pockets: the Ministry of Finance with its power to tax.

To a minor extent, the lender-of-last-resort function can be "privatized," through deposit insurance, the arranging of contingent credit lines, etc. The Ministry of Finance could, if faced with a domestic financial crisis, borrow US dollars and perform the lender-of-last-resort function with these borrowed resources. For truly systemic financial crises this may be inadequate. There is no adequate substitute, in the short run, for the ability to create your own legal tender in unlimited quantities.
When a country (Canada, say) unilaterally adopts another country's currency (the US, say) as its national currency, there is no guarantee whatsoever that the central bank of the country whose currency it has adopted will be willing to act as a lender of last resort for its financial institutions. Unilateral dollarization of this kind therefore carries a very high price tag. The discount window is closed forever and there is no lender of last resort. I therefore assume that the only kind of NAMU Canada might be interested in would be a symmetric monetary union, where the NAMUFed would act as lender of last resort vis-à-vis Canadian financial institutions in exactly the same way as it would vis-à-vis US financial institutions. How this could be achieved without far-reaching political integration is an issue discussed at greater length later in the paper.

\section{Macroeconomic Stabilization: The Theory of Optimal Currency Areas Revisited}

My first maintained hypothesis in what follows is that the current Canadian monetary arrangement (a floating exchange rate with inflation targeting) is capable of delivering, on average and in a sustained manner, an acceptably stable rate of inflation compatible with most reasonable definitions of price stability. The record of the last ten years or so supports this assumption, as seen in Table 2, which also suggests that this price stability has not been purchased at the cost of sustained lower growth or higher unemployment. ${ }^{14}$

Granted then that both the current regime and monetary union with the United States can deliver price stability, the macroeconomic stability issue can be narrowed down to the question as to which regime is more likely to stabilize the real economy, that is, which regime is more likely to avoid or minimize deviations of unemployment from the natural rate or departures of actual from capacity output.

My second maintained hypothesis is that the choice of exchange-rate regime will have no significant impact on the path of capacity output or on the natural rate of unemployment. I therefore rule 
TABLE 2

Inflation, Growth and Unemployment in Canada, 1980-1998

\begin{tabular}{lcccccccccc}
\hline & Av. 1980/89 & 1990 & 1991 & 1992 & 1993 & 1994 & 1995 & 1996 & 1997 & 1998 \\
\hline CPI inflation (\%) & 6.5 & 4.8 & 5.6 & 1.5 & 1.8 & 0.2 & 2.2 & 1.6 & 1.6 & 0.9 \\
GDP deflator inflation (\%) & 5.8 & 3.1 & 2.7 & 1.3 & 1.5 & 1.1 & 2.4 & 1.5 & 0.7 & -0.4 \\
Real GDP growth (\%) & 2.9 & 0.3 & -1.9 & 0.9 & 2.3 & 4.7 & 2.6 & 1.2 & 3.8 & 3.0 \\
Unemployment rate (\%) & 9.3 & 8.1 & 10.4 & 11.3 & 11.2 & 10.4 & 9.5 & 9.7 & 9.2 & 8.3 \\
\hline
\end{tabular}

Source: Statistics Canada and IMFWorld Economic Outlook, December 1998

out a long-run, non-vertical Phillips curve and hysteresis in the natural rate of unemployment. Temporary real shocks only have temporary real effects. Nominal shocks, whether temporary or permanent, are temporary real shocks in my world view. I recognize that monetary shocks, to the extent that they affect investment decisions of any kind (or through such features as overlapping, staggered nominal contracts), can have real effects that may last longer than the nominal rigidities that are responsible for nominal shocks having any real effects at all. I do, however, maintain the assumption that money is neutral in the long run. For practical purposes, we can take the long run to be two years.

How useful a stabilization instrument is monetary policy, working through domestic short nominal interest rates and a floating nominal exchange rate? What does a nation give up, in terms of the ability to pursue macroeconomic stabilization policy by surrendering monetary sovereignty and joining a monetary union and how can it compensate for the loss of the monetary instrument? These are the central questions that produced the theory of optimal currency areas.

The theory of optimal currency areas (Mundell 1961; McKinnon 1963; Ingram 1969; Kenen 1969; Masson and Taylor 1992) is one of the low points of post-World War II monetary economics. Its key failure is a chronic confusion between transitory nominal rigidities and permanent real rigidities. The result is a greatly overblown account of the power of monetary policy to affect real economic performance, for good or for bad.

The optimal currency area literature asks which, of a set of national (or regional) economies each of which has its own national (regional) currency, would benefit from having irrevocably fixed exchange rates with one or more of the other currencies. The following characteristics of either the individual national economies or the multi-country system as a whole, have been argued to favour retention of the national currency and the associated scope for nominal exchange rate flexibility:

- a high degree of nominal rigidity in domestic prices and/or costs;

- a relatively low degree of openness to trade in real goods and services;

- $\quad$ high incidence of asymmetric (nation-specific) shocks rather than symmetric or common shocks and/or dissimilarities in national economic structures or transmission mechanisms that cause 
even symmetric shocks to have asymmetric consequences;

- a less diversified structure of production and demand;

- a low degree of real factor mobility (especially labour mobility) across national boundaries; and

- absence of significant international (and supranational) fiscal tax-transfer mechanisms.

\section{How important are nominal cost and price rigidities in Canada?}

If there are no significant nominal cost and price rigidities, the exchange-rate regime is a matter of supreme macroeconomic insignificance. Only the microeconomic transactions and switch-over costs matter. A country can be mired in real rigidities, and its real economic performance will be miserable. Unless these real rigidities can be addressed effectively through nominal exchange-rate variations, its performance will be equally miserable with a common currency, an independent national currency and a floating exchange rate, or with a system of universal bilateral barter.

The severity and persistence of nominal rigidities, therefore, becomes a key empirical and policy issue. Unfortunately, the available empirical evidence is extremely opaque and very hard to interpret. Information on the duration of nominal wage and price contracts and on the extent to which they are synchronized or staggered is subject to an obvious application of the Lucas critique (Lucas 1976). These contracting practices are not facts of nature, but the outcomes of purposeful choices. Changes in the economic environment conditioning these choices will change the practices.

Testing price and wage data for persistence is equally unlikely to be enlightening. The pattern of serial correlation in the data reflects both "true" structural lags, invariant under changes in the economic environment, and expectational dynamics that will not be invariant when the rules of the game are changed. There is no deep theory of nominal rigidities worth the name.

Menu cost theory assumes that there are real costs associated with changing the prices of goods and services in terms of some numeraire. It does not explain why the numeraire should be money (the means of payment and medium of exchange) or what the consequences would be of a change in the numeraire. Economics has a hard enough time motivating the use of a transactions medium. It has nothing to say about why the numeraire matters. A theory of the numeraire would swiftly land us in the domain of bounded rationality, an area where conventional economists are loath to tread.

This leaves the economics profession in an uncomfortable position. We believe the numeraire matters, although we cannot explain why (using conventional economic tools). We believe that nominal wage and price rigidities are common and that they matter for real economic performance, but we do not know how to measure these rigidities, nor how stable they are likely to be under the kind of policy regime changes that are under discussion. The answer to this key question therefore is: We don't know.

\section{Is Canada too small and/or too open to benefit from exchange rate flexibility?}

A common theme in most optimal currency area approaches is that an economy that is more open to trade in goods and services will lose less when it gives up its national currency. It should be obvious that this proposition cannot be correct as stated. An economy that is completely closed to trade in goods and services neither gains nor loses from a macroeconomic stabilization point of view when it adopts a common currency. If there is a relationship between degree of openness and the cost of giving up exchange-rate flexibility, the relationship cannot be monotone.

A small open economy (a price-taker in the world markets for imports and exports) cannot use 
variations in its nominal exchange rate to affect its international terms of trade. If all final goods and services as well as all intermediate goods and services and raw materials are traded internationally and if the country is small, changes in the nominal exchange rate also will not affect the relative price of traded and non-traded goods (the "real exchange rate"). However, even if final and intermediate goods and services are internationally traded and governed by the law of one price, primary inputs, especially labour services, are unlikely to be internationally traded on a scale sufficient to have the domestic price of labour determined as the product of the exogenous world price of labour and the nominal exchange rate. With labour non-traded, nominal wage rigidities are sufficient to give the nominal exchange rate a (temporary) handle on the real economy, through its ability to influence relative labour costs and profitability.

Canada is a relatively small economy, somewhere between the larger EMU countries like Germany and the small fry like the Netherlands. It may have some limited power to affect its external terms of trade. Its relative price of traded to non-traded goods certainly can be influenced by policy and the presence of immobile labour and nominal wage rigidity means that policy can also influence relative unit labour costs. Potentially therefore, the nominal exchange rate is a stabilization instrument. Canada is open to trade in goods and services (exports were 41 percent of GDP in 1998). ${ }^{15}$ Again, it is somewhere between Germany and the Netherlands in this respect. It is unique in the very high degree of regional concentration of its international trade: in 1998, almost 84 percent of its exports went to the United States and 77 percent of its imports came from the United States. ${ }^{16}$

This geographical concentration of its exports and imports does not mean that a fixed exchange rate with the US would be desirable. If there are frequent and severe shocks to the demand for or supply of exportables and importables, shocks that necessitate a change in the relative price of imports and exports, a floating exchange rate vis-à-vis the US would be desirable. This is a direct application of the "asymmetric-shocks" argument against a common currency, discussed at greater length below. Thus, even if 100 percent of Canada's trade were with the US, this could either be an argument for a common currency (if there are few and only minor asymmetric shocks necessitating a change in the relative price of US and Canadian goods) or a case against it (if frequent and large asymmetric shocks impact on this trading relationship).

I conclude that neither the degree of openness of the Canadian economy nor the concentration of its exports and imports on the US have any obvious bearing on the desirability of Canada joining a NAMU.

\section{Is Canada subject to asymmetric shocks that} make monetary union with the US especially costly?

The "one size fits all" monetary policy corset inflicted on all members of a monetary union is most costly to a member state if it is subject to especially severe asymmetric shocks or if its structure is such as to cause even symmetric or common shocks to have seriously asymmetric impacts on output and employment. The proposition that a monetary union is more attractive when the structure of production and demand is well-diversified should be seen as a statement about the conditions under which asymmetric shocks are less likely.

It is true that giving up nominal exchange-rate flexibility would deprive Canada of a mechanism for responding to asymmetric shocks. While nominal exchange-rate flexibility does not reduce the long-term pain of changing relative costs or prices, it can, if used properly, reduce the transitional costs of achieving the real adjustment that is required. How serious this loss is depends on how well, in practice, this mechanism has been used.

A frequently heard argument is that Canada is likely to be subject to asymmetric supply shocks. 
This is because it has a large commodity producing sector (oil, gas, other natural resources, and agriculture) that is subject to "technological" shocks such as the weather, and to global price shocks. Not only are primary sectors argued to be more prone to supply shocks, than the secondary (manufacturing), tertiary (market services), and quarternary (nonmarket services) sectors, output in these sectors is typically viewed as supply-determined rather than demand-determined. Price determination in markets for primary products is also assumed to be close to the "law of one price" characteristic of integrated markets for homogeneous goods with effective spatial arbitrage.

These characteristics of the primary sectors are clearly potentially relevant to Canada's status as an optimal currency area. However, agriculture's share in Canadian GDP (3 percent in 1996) is no higher than that of most advanced industrial countries. Mining accounts for a larger share of GDP (13 percent in 1996), but, like all modern industrial nations, Canada is overwhelmingly a service economy (67 percent of GDP).

It should also be noted that a flexible exchange rate can be a source of commodity price shocks (for given world commodity prices) as well as a means of responding to changes in world commodity prices.

There are two further considerations that qualify the practical importance of the asymmetric-shocks argument in favour of retaining nominal exchangerate flexibility. Nominal exchange-rate changes are the appropriate response only to asymmetric shocks to the markets for goods and services, that is, to IS shocks and aggregate supply shocks. In response to asymmetric monetary shocks (LM shocks), a constant nominal interest rate is appropriate. In a world with perfect international financial capital mobility, a constant nominal interest rate translates into a constant expected rate of exchange-rate depreciation. A fixed exchange rate is one way of delivering this optimal response to LM shocks. ${ }^{17}$
Second, it is important not to be excessively impressed with the efficiency of financial markets in general, and with the efficiency of the foreign exchange market in particular. Most of the time, the foreign exchange market is technically efficient, in the sense that large transactions can be made almost instantaneously, at very low transactions costs and with a minimal impact on the exchange rate. ${ }^{18}$ Even if the foreign exchange market is technically efficient (in the weak, semi-strong or even the strong sense) and no risk-adjusted pure profits can be made, the price established in this technically efficient market may not convey the right social scarcity valuation. Rational speculative bubbles can cause an asset price like the exchange rate to differ from its fundamental valuation. Departures from technical efficiency also are common. Herding instinct, bandwagon effects and other irrational behaviour, noise traders, panic traders, and traders caught in a liquidity squeeze in other financial markets make for excessive volatility and sometimes quite persistent misalignments in the foreign exchange markets.

The foreign exchange market and the exchange rate can therefore be a source of extraneous shocks as well as a mechanism for adjusting to fundamental shocks. One cannot have the one without the other. The potential advantages of nominal exchange-rate flexibility as an effective adjustment mechanism or shock absorber are bundled with the undoubted disadvantages of excessive noise and unwarranted movements in the exchange rate, inflicting unnecessary real adjustments on the rest of the economy. It is by no means clear that the advantages of nominal exchange rate flexibility when faced with fundamental asymmetric shocks dominate its disadvantages as a source of extraneous asymmetric shocks.

\section{Is limited real resource mobility an obstacle to NAMU?}

It is clear that a high degree of real factor mobility can be an effective substitute for nominal exchangerate adjustments in the face of asymmetric shocks. Indeed, factor mobility permits long-term, even 
permanent real adjustments to asymmetric real shocks, something nominal exchange flexibility cannot deliver.

The real factors whose mobility matters are labour and real capital. Real capital mobility is limited, even when financial capital mobility is perfect. Once real capital (plant, machinery and other equipment, infrastructure, etc.) is installed, it becomes hard to shift geographically. There are some examples of "flying capital," such as Jumbo jets, and there have been examples of whole factories being shipped over great distances by rail, but as a first approximation, real capital cannot be relocated. New gross investment can, of course, be redirected across national boundaries, and financial capital mobility can facilitate this process, by permitting the decoupling of national saving and gross domestic capital formation. This is not a process that is likely to be very significant at cyclical frequencies, however. Moving the real capital stock between Canada and the United States through variations in gross investment flows is therefore unlikely to be an effective substitute for the short-term stabilization potential of nominal exchange-rate movements.

A similar point can be made about international labour mobility. Canada is historically a nation of immigrants. Even in 1996, the census report for that year reveals that out of a total population 5 years old and over of 26.6 million, 928 thousand were external migrants (defined as people who were living outside Canada five years earlier) (Statistics Canada 1996). From the point of view of monetary union with the US, however, what matters is net migration flows between the US and Canada, and these figures are much more modest. Cultural and linguistic obstacles to mobility between the US and Canada may be less than between most EMU members. Most Canadians have some version of English as either their first or second language. However, legal and administrative obstacles to labour mobility between the US and Canada are much more severe than among EMU members. Throughout the EU, work permits are a thing of the past, and mu- tual recognition of professional qualifications is becoming the norm rather than the exception.

Unless monetary union between the US and Canada were to be accompanied by the complete removal of legal and administrative obstacles to cross-border labour mobility, it is very unlikely that labour mobility could become an effective substitute for nominal exchange-rate flexibility. Even with unrestricted cross-border labour mobility, it is unlikely that labour mobility could mimic the impact of variations in the nominal exchange rate. Migration is costly, within as well as between nations. Workers are only likely to move if the fixed, upfront cost of moving is compensated for by a long period of higher earnings in the country of destination. Permanent (or at least persistent) real shocks will trigger labour mobility. Nominal exchange-rate flexibility only affects the real economy for a short transition period. To mimic the effect of nominal exchange-rate flexibility, net cross-border migration flows would have to be reversible and significant at cyclical frequencies. It is hard to see that happening.

I conclude that cross-border mobility of real capital and of labour between the US and Canada is unlikely to be an effective substitute for nominal exchange-rate flexibility. However, I doubt that even within existing currency unions (like the US), net interregional migration flows are quantitatively important at cyclical frequencies. This means one of two things. Either, these existing currency unions are not optimal currency areas or an optimal currency area does not require a high degree of labour mobility at cyclical frequencies.

\section{Is a strong NAMU federal fiscal authority necessary to compensate for the loss of the exchange-rate instrument?}

The brief answer is "no." Fiscal stabilization policy works if and to the extent that postponing taxes, and borrowing to finance the resulting revenue shortfall, boosts aggregate demand. This will be the case either if there is myopia among consumers, who fail to realize that the present value of current and future 
taxes need not be affected by the timing of taxes, or if postponing taxes redistributes resources between households with different propensities to consume. In overlapping generations models without an operative intergenerational gift motive, postponing taxes redistributes resources from the young to the old and from generations yet to be born to generations already alive. This will boost aggregate consumption in the short run. Intra-cohort heterogeneity (say through the coexistence of lifecycle consumers and current disposable-income-constrained consumers) can reinforce these effects.

Unless the supranational Federal Fiscal Authority in a currency union has access to the financial markets on terms that are superior to those enjoyed by the national fiscal authorities, there is nothing the federal authorities can achieve by way of fiscal stabilization that cannot be achieved equally well by national or even lower-tier fiscal authorities. National government financial deficits and surpluses, probably mirrored to some extent in national current account imbalances, are a perfect substitute for supranational fiscal stabilization.

A study by Bayoumi and Masson (1993), building on earlier work by Sala-i-Martin and Sachs (1992), analyzes regional flows of federal taxes and transfers within the US and Canada. They try to distinguish between long-term fiscal flows (the redistributive element) and short-term responses to regional business cycles, which they identify with the stabilization element. They find that in the US, long-run flows amount to 22 cents in the dollar while the stabilization element is 31 cents in the dollar. For Canada, the corresponding figures are 39 cents and 17 cents respectively. While interesting, these studies tell us nothing of relevance to the issue of whether fiscal policy in a NAMU could compensate for the loss of the exchange-rate instrument. The long-term redistribution properties of the budget are irrelevant, because the nominal exchange rate is not an instrument for long-term redistribution. The stabilization properties of the fiscal system do matter, but the necessary stabilization can be pro- vided at the supranational, national or subnational level.

It is true that, to the extent that monetary union is part of a wider process of political integration, the political pressures may grow for long-term redistribution among the nations that constitute the monetary union. What the redistribution figures in the studies of Bayoumi and Masson and of Sala-iMartin and Sachs tell us, is the degree to which the United States and Canada are societies, rather than just economies, and the extent to which notions of national solidarity and regional social cohesion are translated into redistributive measures through the tax-transfer mechanism.

I conclude that the likely continued absence of a strong North American Fiscal Authority with serious transnational tax and transfer powers, is not a technical, economic obstacle to NAMU.

\section{Political and Constitutional Aspects of Monetary Union}

Monetary union is not just a technical, economic, financial or monetary issue. It represents a very significant constitutional and political change. Monetary union raises two distinct but related political and constitutional issues: first the legitimacy of the surrender of national sovereignty involved in NAMU and second, the accountability of the monetary policymakers to the electorate or its elected representatives.

\section{National Sovereignty}

Monetary union represents a surrender of national sovereignty to a supranational entity. This is true even for the full, formally symmetric monetary union that I have focused on. A central bank is a key agent of the state. The ability to issue legal tender is an expression of the power of the state to coerce, to prescribe and proscribe behaviour. The common use of the term "seigniorage" to refer to the revenues accruing to the state through its monopoly of 
legal tender is a reminder of the fact that the power to issue legal tender is a manifestation of the state's ability to tax. A nation that joins a monetary union surrenders its national sovereignty in the monetary domain and becomes subject to a supranational form of sovereignty. The nation state is weakened by this surrender of monetary sovereignty. I am not expressing myself on whether this would be a good thing or a bad thing for Canada. ${ }^{19} \mathrm{I}$ am merely reporting the fact.

The concepts of "national sovereignty" and of the "state" are fraught with ambiguity. A unitary nation state can be sovereign in the legal sense of the word, but the effective domain over which this sovereignty can be exercised may be negligible, because of the size of the country and its openness to trade, financial flows, and factor mobility. Luxembourg is a sovereign state. ${ }^{20} \mathrm{~A}$ federal state has sovereignty exercised over different domains at different levels. The states of the US, the provinces of Canada, and the cantons of Switzerland exercise sovereignty in a number of domains. They are, of course, part of a wider (national) monetary union. From the perspective of state or provincial sovereignty, the only question is which monetary union it belongs to: the US or Canadian monetary union, or a common NAMU.

The sober reality of this partial surrender of national sovereignty is complicated by the strong symbolic significance often attached to the national currency. The irreducible minimal list of symbols that define the state include a national currency, along with an anthem and a flag. ${ }^{21}$ The emotions that are awakened when the abolition of the national currency is under discussion go beyond what can be rationalized in terms of concerns about the loss of national discretion in the use of seigniorage or the loss of the national monetary stabilization instrument. $^{22}$

These constitutional issues are very clear in the case of EMU. Economic and monetary union in Europe is part of an ongoing process of economic and political integration in Europe, and not an iso- lated, "technical," monetary arrangement. In this it differs from arrangements like the classical gold standard, which flourished between 1880 and 1914, the heyday of European imperialism and nationalism. EMU is foremost a major step on the road to "ever closer union" in Europe. It represents the opening of a new chapter in the European federalist agenda, a significant transfer of national sovereignty to a supranational institution.

Like EMU, NAMU would involve a transfer of national sovereignty to the central or federal level. Unless this transfer of power is perceived as legitimate by NAMU residents, the authority of the NAMUFed will be challenged by those who perceive themselves to be adversely affected by it. In the past, common currency arrangements, including a supranational central banking system with centralized authority, have survived only when, at the time of their creation, a stronger and more legitimate federal government structure was in place than is currently the case in the EMU area. A fortiori, past common currency arrangements have been supported by a level of political integration way beyond the zero level currently found in North America. ${ }^{23}$ The EU has, at present, only a very weak, proto-confederal set-up, but it does have a Parliament, a Court and a proto-executive, made up of the Commission and the Council of Ministers. NAMU would not be supported by any supranational political legitimizing structures. For that reason alone, I very much doubt it could survive. A break-up of NAMU would be messy and disruptive.

The track record of past monetary unions is instructive. For instance, monetary union in the United States was not complete until long after political unification. While one can make allowances for the war period (1776-83) and for the Confederation period (1783-89), even the US monetary union created with the signing of the Constitution in 1789, was far from complete. While the Constitution gave Congress the monopoly of coinage and of the regulation of its value, the states continued to be able to charter commercial banks and to regulate their note 
issuance. Until the creation of the Federal Reserve System in 1914, the US did not have a central bank, although the First Bank of the US (1791-1811) and the Second Bank of the US (1816-36) can perhaps be characterized as proto-central banks. ${ }^{24} \mathrm{~A}$ monetary union with a centralized authority really did not exist in the United States until the Banking Act of 1935 .

Italian monetary unification occurred in 1862 , with the introduction of a new unified coinage system, based on the Sardinian lira, after political unification had been completed in $1861 .{ }^{25}$ Centralization of note and coin issuance and of other central bank functions did not occur until 1893.

The history of German monetary and political union in the nineteenth century is open to two very different interpretations. The political establishment of the German Reich in 1871, following the FrancoPrussian war, preceded the coinage acts of 1871 and 1873, which unified coinage throughout the Reich and introduced the mark and the unit of account. In 1875, the new Reichsbank (a re-labelling of the Prussian bank) became the de facto central bank of the Reich. In practice, it monopolized the issuance of notes. In 1875, Germany went on the gold standard (Germany used the Franco-Prussian War indemnity of 1870 to finance the creation of a gold standard an early example of the use of Regional Funds to facilitate monetary integration perhaps). This sequence of events suggests that political unification in Germany preceded monetary union.

Against that, the customs union (Zollverein) of 1834 was followed by the Munich Coin Treaty of 1837 and the Dresden Coinage Convention of 1838, which created a double currency standard among all members of the Zollverein and most members of the Deutscher Bund. In 1857, the Vienna Coinage Treaty joined Austria to the Dresden arrangement. On this reading, most of the key steps toward German monetary unification were taken before political unification. It should, however, be noted that Austria left the Vienna arrangement in 1867 following defeat in its war with Prussia. It did not join the German Reich in 1871 .

German political reunification in 1990 coincided with monetary union between the former West and East Germanies (GEMU). This is not an event with any clear implications for EMU, since GEMU was little more than a take-over of a near-bankrupt East Germany by West Germany.

There have been exceptions to the rule that political unification precedes monetary union. Even if one ignores the ambiguous German nineteenthcentury experience, the seven provinces that formed the Dutch Republic established a monetary union with only the weakest (con)federal political institutions and with almost completely decentralized fiscal authority. It lasted for two centuries, until the conquest of the Republic by Napoleon (Dormans 1991).

Belgium and Luxembourg were in a monetary union from 1922 until they were both absorbed in Euroland in 1999. While this association is more akin to a union between an elephant and a mouse (and belongs in the France-Andorra, FranceMonaco, Italy-Vatican City, Italy-San Marino, Switzerland-San Marino category), it is interesting that monetary union did not lead to far-reaching political integration between Belgium and Luxembourg.

Slightly different in nature are the currency unions adopted by contiguous former colonies following independence. The CFA Franc Zone, set up in 1959 by 13 former French colonies in west and central Africa, still survives, although the CFA franc was devalued by 50 percent in 1994 . The survival of the arrangement appears to owe much to the continued involvement of (and budgetary transfers from) France. The East Caribbean Currency Area, consisting of seven former British colonies, has survived since 1966, unlike the East African Currency Area between Kenya, Uganda, and Tanzania which lasted only from 1966 until 1977. 
Monetary unions that occurred without prior political unification and did not subsequently lead to political unification, have very low lifeexpectancies. The only exceptions to the rule I am aware of are Belgium and Luxembourg. Examples of an early death include the following:

- The Latin Monetary Union among France, Belgium, Switzerland and Italy, which lasted (with some temporary suspensions of convertibility by individual members) from 1865 until, de facto World War I. The official time of death was 1927.

- The Scandinavian monetary union among Sweden, Denmark, and Norway, which lasted from 1873 until de facto World War I, although the arrangement was not officially put out of its misery until 1924.

Attempts by "successor states" to maintain monetary union following the breakup of a larger political entity, have been short-lived, with the possible exception of the "monetary union" between the UK and Ireland (a currency board arrangement for Ireland, rather than a "symmetric" monetary union), which lasted from 1922 until 1979.

Examples of spectacular failures to maintain a common currency following a political breakup include the successor states of the Austro-Hungarian Empire following the defeat of the Hapsburg Empire in World War I; the ill-fated rouble zone among 11 CIS members between 1991 and mid-1993, following the dissolution of the Soviet Union; and the collapse of the monetary union among the successor states to the Federal Republic of Yugoslavia, which dissolved in $1991 .{ }^{26}$ All three political breakups led to hyper-inflations.

Czechoslovakia broke up as a political union on 1 January 1993; the Czech-Slovak monetary union collapsed on 8 February 1993 (Fidrmuc and Horváth 1998). Here the political and monetary breakup was not accompanied by hyper-inflation.
I have considerable sympathy for the longstanding German position that, in the context of the European Economic and Monetary Union, further political integration should have accompanied (or even preceded) monetary union..$^{27}$ On the other hand, the whole European integration experiment, from the Coal and Steel Community on, has been a political wolf dressed in economic sheep's clothing. It has been successful so far, and it may well continue to be so. ${ }^{28}$ It is essential, however, that the European Parliament, backed by the European Court and the Ombudsman, act as an effective watchdog over the ECB. The legitimacy of the ECB will depend on the extent to which it is effectively accountable to the European Parliament. There is no counterpart in North America to the European Parliament, the European Court, and the Ombudsman. The transfer of national sovereignty involved in the creation of NAMU would therefore not be perceived as legitimate.

\section{Accountability of the NAMUFed}

Monetary policy in a NAMU would be made by an operationally independent central bank, the NAMUFed. The targets or objectives of the central bank should, of course, be politically determined, as they are in Canada, the US, the UK, Japan, Sweden, and the EMU. In an open, democratic society the delegation of policy-making powers to unelected officials will only be accepted as legitimate by the citizens, if the independent central bank is accountable to the elected representatives. Accountability requires openness and transparency. The objective or objectives of the central bank must be clear and unambiguous. This is essential if the electorate and its elected representatives are to be able to judge the performance of the central bank.

The need for openness and transparency also applies to the procedures of the central bank. Individual voting records of the members of the central bank's decision-making council should be in the public domain. So should the minutes of its meetings. More elaborate and in-depth analyses of the council's thinking (like the Bank of England's 
quarterly inflation report and inflation forecast) should be published regularly. An independent body (like the Non-Executive Directors of the Court of the Bank of England) should vet the procedures of the central bank and its council on a regular basis, and should have the power to make binding recommendations. This procedural openness and accountability is essential for two reasons. First, it is the only effective instrument of quality control for an operationally independent central bank. Second, openness, transparency, and accountability of any agent of the state is a political public good. If any state agency can deny information to its citizens on grounds other than clear and present danger to the public interest, the citizen's right to know is impaired across the board. Sunshine Laws, openness, freedom of information, and accountability are an essential defence of the citizen against a powerful and overbearing state.

At the core of effective accountability is the need for the council members, collectively and individually, to justify themselves before a duly constituted parliamentary committee. In the US, the governor of the Fed appears periodically before Congress. In Euroland, the Subcommittee on Monetary Affairs of the European Parliament is charged with the political supervision of the ECB. In the UK, committees of both the House of Commons and the House of Lords call Monetary Policy Committee (MPC) members to appear on a regular basis to explain their actions. ${ }^{29}$

I recognize that, both as regards the clarity of the politically mandated objectives of monetary policy, and as regards the procedural openness and transparency of the monetary policy framework, Canada, like the ECB, may still fall somewhat short of current best practice. Current best practice itself remains, of course, eminently improvable. However, in Canada, in the EMU zone, and in the realms of current best practice, the political mechanisms exist to improve the rules of the monetary policy game. The Canadian and European Parliaments can, should they wish to do so, impose true accountability on the central banks operating in their respective jurisdictions.

In North America, there is no parliament that could enforce effective accountability of the NAMUFed. Even if Canada were to get a seat on the NAMUFed council, the Canadian Parliament would only be able to call its single representative to account. The non-Canadian majority on the NAMUFed council would be under no obligation to answer to the elected representatives of the citizens of Canada. The US Congress could hardly be expected to act in loco parentis for the Canadian Parliament on monetary matters. Such an arrangement would not, in my view, be acceptable to the citizens of Canada (nor to those of the United States).

\section{Conclusion}

I conclude that the technical, economic case for Canadian membership in a NAMU is quite finely balanced, but in favour of monetary union if the monetary union in question were a full, formally symmetric monetary union. This would give Canada a reasonable share of NAMU seigniorage; it has the NAMUFed assuming full lender-of-last-resort responsibilities for Canadian financial institutions; the NAMUFed defines its price stability and other economic objectives with reference to the entire NAMU area; and it gives Canada a voice and a vote on the NAMUFed's decision-making council commensurate with its economic weight.

Unilateral "dollarization," where a "peripheral" country simply adopts the currency of another ("centre") nation, without a fair share of the common seigniorage, without access to the discount window and other lender-of-last-resort facilities, and without a voice in the decision-making processes of the centre country's central bank would not make economic sense. While the macroeconomic stability arguments and the microeconomic resource savings arguments would still favour monetary union, the seigniorage and lender-of-last-resort 
considerations would dominate. Unilateral dollarization should be of interest only to a chronically mismanaged economic basket case, whose sole hope of achieving monetary stability is to unilaterally surrender monetary sovereignty. Neither Canada nor Mexico fall into that category.

While the economic pros and cons of NAMU are rather finely balanced, the political arguments against it appear to be overwhelming. The absence of effective North America-wide political institutions means that there could be no effective political accountability of the NAMUFed. The surrender of political sovereignty inherent in NAMU would therefore not be perceived as legitimate by a sophisticated citizenry, used to accountability as a right not as an optional extra.

Critics of EMU have pointed out that the EMU is a small, flightless bird, surviving precariously in arid surroundings. I actually believe that the EMU will fly, and that it will prosper, because it is part of an ongoing process of political unification in Europe. NAMU, however, will not fly, except as part of a wider political movement toward far-reaching political integration, a United States of North America. And there is no sign of that.

\section{ACKNowledgement}

I would like to say a few words about the man whose memory we honour with this lecture series. Doug Purvis was a very fine economist, with an uncanny knack for stripping away the inessential in order to focus, in the most transparent manner, on the key issues. He was invariably motivated by the key macroeconomic policy issues of the day. Indeed, he was passionate about the use of economic theory as a tool for improving the conduct of economic policy and the quality of life. His activities as a policy adviser, in Canada and abroad, bear testimony to his ability to arbitrage effectively between the domains of scholarship and policy advice. His unexpected, tragic death was a terrible blow for all those who knew and loved him. I will always miss his larger than life presence, his warmth, his wit, and the quality of his intellect. How wonderful it would have been to be able to hear his views on North American Monetary Union!

\section{Notes}

The views and opinions expressed are those of the author only. They do not necessarily reflect the views and opinions of the Bank of England or of the other members of the Monetary Policy Committee. I would like to thank Lars Osberg for insightful comments on an earlier draft of the paper.

'Technically, the national central banks are the share-
holders of the ECB. The Maastricht and Amsterdam trea-
ties distinguish between the ECB and the European Sys-
tem of Central Banks (ESCB), the collective of the ECB
and the national central banks. In publications of the ECB
and in public statements of its Executive Board members,
there are frequent references to the "Eurosystem" (an
obvious echo of the Federal Reserve System). Each na-
tional central bank provides one member of the decision-
making Governing Council of the ECB (which consists
of the 11 national central bank governors and six execu-
tive board members) and certain aspects of the implemen-
tation of the centrally determined monetary policy are
administratively decentralized through the NCBs. None
of this detracts from the reality that the ECB/ESCB is a
"unitary" central bank. Monetary policy authority is un-
ambiguously centralized in Frankfurt and, the NCBs have
effectively become the regional branch banks of the ECB.

${ }^{2}$ See e.g., Courchene 1993, 1998; Suttle 1999; and Laidler 1999. Unilateral dollarization has also been proposed for Argentina, which currently has a currency board arrangement with the US dollar.

${ }^{3}$ The target for inflation is supposed to be a range for the annual proportional rate of increase in the CPI of between 1 and 3 percent. It is unclear whether this target range is symmetric around 2 percent. My reading of the recent policy record and of statements by top officials from the Bank of Canada and the federal Department of Finance suggest that a given positive deviation from 2 percent inflation would be frowned upon more than an equal negative deviation. 
${ }^{4}$ Formal symmetry means that participating nation states share in the costs and benefits of the monetary union in a way that represents their economic size or weight, and that their representation on the decision-making council of the supranational central bank (the NAMUFed) likewise reflects their economic importance in the union. Clearly, in a formally symmetric union between countries of very different economic size, the larger member(s) will be the dominant partners. In a NAMU, the US would effectively run the show.

${ }^{5}$ For concreteness, I will only consider the case of a unilateral adoption of the US dollar by Canada. The case of a unilateral adoption by the United States of the Canadian dollar would be more fun, but less relevant. Henceforth, dollarization means $U S$-dollarization.

${ }^{6}$ The United States is unusual in having three targets: maximum employment, price stability, and interest rate stability.

${ }^{7}$ I must confess, however, to being still quite befuddled about the meaning and role of the monetary conditions index in the conduct of Canadian monetary policy (see Freedman 1995).

${ }^{8}$ I am restricting the discussion to market-based methods of monetary control. Credit rationing, etc. are not considered.

${ }^{9}$ Assume for simplicity that the risk and return properties of the US and Canadian TBs are identical. If the Canadian government issued US dollar-denominated TBs in addition to Canadian dollar-denominated TBs, currency risk considerations could even trigger the sale and purchase of TBs denominated in different currencies without this involving any foreign exchange transactions. This would be the case if Canadian government US dollardenominated TB sales could be paid for in Canadian dollars.

$$
\begin{array}{ll}
10 & 1+\pi_{t} \equiv \frac{P_{t}}{P_{t-1}} \\
11 & m_{t} \equiv \frac{M_{t}}{P_{t} Y_{t}} \\
12 & 1+g_{t} \equiv \frac{Y_{t}}{Y_{t-1}}
\end{array}
$$

${ }^{13}$ In 1998, Canada's population size was 11.34 percent of the US population size. Canada's 1997 GDP was
8.14 percent of US GDP (using purchasing power parity (PPP) measures). US seigniorage (the change in the stock of currency) for the past five years is shown in the table below.

\section{US Seigniorage \\ (US\$billion)}

\begin{tabular}{llllll}
\hline & 1994 & 1995 & 1996 & 1997 & 1998 \\
\hline Seigniorage & 32.0 & 18.2 & 21.7 & 31.1 & 34.7 \\
\hline
\end{tabular}

${ }^{14} \mathrm{My}$ rather sanguine view of the costs associated with the pursuit of price stability is by no means universally shared. For a contrary opinion see e.g., Osberg and Fortin (1998). Targeting very low inflation does increase the risk that the economy will end up in a liquidity trap. For a discussion of this issue, see Buiter and Panigirtzoglou (1999).

${ }^{15}$ Value-added in exports is bound to be less than total exports, which includes re-exported imported raw materials and intermediates.

${ }^{16}$ The figures for Mexico are 84 percent for exports and 75 percent for imports.

${ }^{17}$ This is a straightforward extension of Poole (1970) to an open-economy setting with integrated global financial markets; see Buiter (1997).

${ }^{18}$ Like other financial markets, the foreign exchange markets are at times beset by "disorderly market conditions," in which spreads widen to the point that transactions dry up and the market ceases to be efficient, even in the narrow technical sense.

${ }^{19}$ In the context of European monetary integration, I have been an enthusiastic supporter of the surrender of national sovereignty involved in EMU. The reason is overwhelmingly political: fear and loathing of the unparalleled destructive capacities of European nationalism.

${ }^{20}$ It was in a currency union with Belgium from 1922 until 1999.

${ }^{21}$ Thanks to Lars Osberg, I am now aware of the fact that Canada did not have an official flag until 1965 or official national anthem until 1980.

${ }^{22}$ Similar emotions are involved when, in a decentralized, federal system, the issue of which flag or flags to 
fly from government buildings is at stake. The flying of the Confederate flag in the US South is one example of this. In Canada too, the symbolism of the national and provincial flags evokes powerful emotions.

${ }^{23}$ I do not consider NAFTA, a regional free trade arrangement, to have any serious supranational institutional content.

${ }^{24}$ The Federal Reserve Act was signed into law on 23 December 1913.

${ }^{25}$ Venetia was incorporated in 1866 . The Papal States followed in 1870, when the French were otherwise engaged and could not intervene to protect their independence.

${ }^{26}$ Ukraine left the rouble zone in 1992. Tajikistan did not establish its own currency until 1995.

${ }^{25}$ See e.g., Tietmeyer $(1998 a, b)$. For a general discussion, see Eichengreen (1996).

${ }^{28}$ There have been times, however, that the economics got too far ahead of the politics. The Werner Group's recommendation in 1970 of full monetary union by 1980 clearly was a bridge too far at the time.

${ }^{29}$ In the UK, there is a further dimension of political accountability. If the inflation rate departs from the politically mandated target by more than 1 percent in either direction, the governor of the Bank of England has to write an open letter to the Chancellor of the Exchequer. In that letter he has to explain why the departure from the target happened, what the MPC proposes to do about it, over what time horizon it expects to be back on track, and how all this is consistent with the MPC's mandate.

\section{REFERENCES}

Allison, T.E. (1998), "Overall Impact of Euro Banknotes on the Demand for U.S. Currency." Testimony before the Subcommittee on Domestic and International Monetary Policy, Committee on Banking and Financial Services, U.S. House of Representatives: http:// www.federalreserve.gov:80/BoardDocs/Testimony/ 1998/19981008.htm (8 October).

Bank of Canada (1999), Annual Report 1998 (Ottawa: Bank of Canada).

Bayoumi, T. and P.R. Masson (1995), "Fiscal Flows in the United States and Canada: Lessons for Monetary
Union in Europe," European Economic Review 39:25374.

Buiter, W.H. (1997), "The Economic Case for Monetary Union in the European Union," in European Economic Integration, ed. C. Deissenberg, R.F. Owen and D. Ulph, supplement to the Review of International Economics 5(4):10-35.

(1999), "Alice in Euroland," Journal of Common Market Studies (forthcoming).

Buiter, W.H. and N. Panigirtzoglou (1999), "Liquidity Traps: How to Avoid Them and How to Escape Them," (Bank of England, unpublished paper, May); also http:/ /www.econ.cam.ac.uk/faculty/buiter/index.htm

Buiter, W.H, G. Corsetti and P. Pesenti (1998), Financial Markets and European Monetary Cooperation; The Lessons of the 92-93 ERM Crisis (Cambridge: Cambridge University Press).

Courchene, T. J. (1993), "Reflections on the Canadian Federalism: Are there Implications for the European Economic and Monetary Union?" European Economy, Special Issue 4:23-166.

(1998), "Towards a North American Common Currency: An Optimal Currency Area Analysis," (Kingston: Queen's University, unpublished paper).

Dormans, E.H.M. (1991), Het Tekort( Amsterdam: NEHA).

Dowd, K. and D. Greenaway (1993), "Currency Competition, Network Externalities and Switching Costs: Towards an Alternative View of Optimum Currency Areas," Economic Journal 102:1180-89.

Eichengreen, B. (1996), "On the Links Between Monetary and Political Integration,"(University of California at Berkeley, unpublished paper).

Engel, C. and J.H. Rogers (1996), "How Wide is the Border," American Economic Review 86(5): 1112-225.

European Economy (1990), One market, one money; An evaluation of the potential benefits and costs of forming an economic and monetary union, No 44, October.

Fidrmuc, J. and J. Horváth (1998), "Stability of Monetary Unions: Lessons from the Break-up of Czechoslovakia," Discussion Paper No. 9874 (Tilburg: CentER for Economic Research, Tilburg University, The Netherlands).

Freedman, C. (1994), "The Use of Indicators and of the Monetary Conditions Index in Canada," in Frameworks for Monetary Stability: Policy Issues and Country Experiences, published under the direction of T.J.T. Baliño and C. Cottarelli (Washington, DC: International Monetary Fund). 
(1995), "The Role of Monetary Conditions and the Monetary Conditions Index in the Conduct of Policy," paper presented at the Conference on International Developments and the Economic Outlook for Canada, organized by the Policy and Economic Analysis Program, Institute for Policy Analysis, University of Toronto, 15 June.

Furstenberg, G. von, and M. Fratianni (1996), "Monetary Union: Still Coming in Europe and North America?" Challenge, July-August, pp. 34-39.

Ingram, J. (1969), “The Currency Area Problem,” in Monetary Problems of the International Economy, ed. R.A. Mundell and A.K. Svoboda (Chicago, IL: Chicago University Press).

Kenen, P. (1969), "The Theory of Optimal Currency Areas: An Eclectic View," in Monetary Problems of the International Economy, ed. R. A. Mundell and A.K. Svoboda (Chicago, IL: Chicago University Press).

Laidler, D. (1999),"The Exchange Rate Regime and Canada's Monetary Order,' Working Paper 99-7 (Ottawa: Bank of Canada).

Lucas, R.E., Jr. (1976), "Econometric Policy Evaluation: A Critique," in Carnegie-Rochester Conference Series on Public Policy Vol. 1, ed. K. Brunner and A.H. Meltzer (Amsterdam: North Holland).

McKinnon, R.I. (1963), "Optimum Currency Areas," American Economic Review 53:717-25.

Masson, P.R. and M.P. Taylor (1992), "Common Currency Areas and Currency Unions: An Analysis of the Issues," CEPR Discussion Paper No. 644 (Cambridge: Centre for Economic Policy Research).

Mundell, R.A. (1961), "A Theory of Optimum Currency Areas," American Economic Review 51: 657-75.
Osberg, L. and P. Fortin, eds (1998), Hard Money, Hard Times; Why Zero Inflation Hurts Canadians (Toronto: James Lorimer \& Co. Publishers).

Poole, W. (1970),'Optimal Choice of Monetary Policy Instruments in a Simple Stochastic Macromodel," Quarterly Journal of Economics 84:197-216.

Sala-i-Martin, X. and J. Sachs (1992), "Fiscal Federalism and Optimum Currency Areas: Evidence from Europe and from the United States," CEPR Discussion Paper No. 632 (Cambridge: Centre for Economic Policy Research).

Statistics Canada (1996), Census Nation Tables Series (Ottawa: Supply and Services Canada).

Suttle, P. (1999), "Monetary Union in the Americas," Current Economics (March):3-6.

Thiessen, G. (1998), The Canadian Experience with Targets for Inflation Control, The Gibson Lecture (Kingston: School of Policy Studies, Queen's University).

(1999), "The euro: Its economic implications and its lessons for Canada," Remarks to the Canadian Club of Ottawa, 20 January.

Tietmeyer, H. (1998a), "Political Consequences of Monetary Union," Speech given at the Social Congress of the Commission of Bishop's Conferences of the European Community, 20 February.

(1998b), "Eine stabile Währung als Grundlage für die Soziale Marktwirtschaft," lecture given on the occasion of the sixth Alfred Müller-Armack-Symposium der Aktionsgemeinschaft Soziale Marktwirtschaft in Tübingen on 5 November. 